Abstracta Iranica Abstracta Iranica

Revue bibliographique pour le domaine irano-aryen

Volume 25 | 2004

Comptes rendus des publications de 2002

\title{
Evrazija : Narody i mify. Moscou, Natalis Press, 2003, 607 p., [18] ill. [Eurasie : Peuples et mythes]
}

\section{Stéphane A. Dudoignon}

\section{(2) OpenEdition}

1 Journals

\section{Édition électronique}

URL : http://journals.openedition.org/abstractairanica/4036

DOI : 10.4000/abstractairanica.4036

ISSN : 1961-960X

Éditeur :

CNRS (UMR 7528 Mondes iraniens et indiens), Éditions de l'IFRI

\section{Édition imprimée}

Date de publication : 15 mai 2004

ISSN : 0240-8910

Référence électronique

Stéphane A. Dudoignon, «Evrazija : Narody i mify. Moscou, Natalis Press, 2003, 607 p., [18] ill. [Eurasie Peuples et mythes] », Abstracta Iranica [En ligne], Volume 25 | 2004, document 9, mis en ligne le 15 mars 2006, consulté le 25 septembre 2020. URL : http://journals.openedition.org/abstractairanica/ 4036 ; DOI : https://doi.org/10.4000/abstractairanica.4036

Ce document a été généré automatiquement le 25 septembre 2020.

Tous droits réservés 


\title{
Evrazija : Narody i mify. Moscou, Natalis Press, 2003, 607 p., [18] ill. [Eurasie : Peuples et mythes]
}

\author{
Stéphane A. Dudoignon
}

L'ouvrage reprend les articles publiés dans la revue moscovite Acta Eurasica / Vestnik Evrazii depuis sa création, en 1996, jusqu'à l'année 2002. La revue couvre l'ensemble de l'Eurasie post-soviétique et, en rupture avec les approches orientalistes longtemps dominantes en URSS, accorde une place particulièrement importante aux sciences sociales - dans la perspective, en particulier, de la revisitation actuelle des grands mythes fondateurs, à la lumière des relations entre l'État et la société. Contributions importantes sur la sociologie des migrations (réfugiés russes d'Asie Centrale en Fédération de Russie, tadjiks en Sibérie occidentale, etc.), sur les mouvements sociaux des trente dernières années (bandes de jeunes des grandes villes de l'URSS), sur l'histoire des perceptions et représentations de l'Eurasie Centrale (par les autorités coloniales au $19^{\mathrm{e}} \mathrm{S}$., par le mouvement "eurasien» des années 1920, aujourd'hui réinterprété, etc.). Sa méfiance à l'égard des catégories établies, son esprit comparatiste, son effort de vision diachronique et son ouverture aux contributions internationales font, notamment, le grand prix de cette publication ó devenue en quelques années l'une des tribunes majeures de la recherche sur les sociétés contemporaines d'Eurasie Centrale.

\section{INDEX}

Thèmes : 1.2. Recueils d'articles : revues, colloques, ouvrages collectifs 


\section{AUTEURS}

\section{STÉPHANE A. DUDOIGNON}

Université Marc Bloch - Strasbourg 